\title{
Method for increasing the ecological and food values of milk and dairy products
}

\author{
M.G. Kokaeva ${ }^{1}$, R.B. Temiraev ${ }^{1 \& 2}$, A.S. Dzhaboeva ${ }^{3}$, R.V. Osikina ${ }^{1}$, \\ M.S. Gazzaeva ${ }^{2}$, L.H. Shugusheva ${ }^{4}$, I.K. Sattsaeva ${ }^{5}$, L.P. Nerovnykh ${ }^{6}$, \\ G.Y. Arutyunova ${ }^{6}$, B.S. Efendiev ${ }^{4}$
}

\begin{abstract}
${ }^{1}$ North-Caucasian Mining and Metallurgical Institute (State Technological University), Vladikavkaz, 362021, ${ }^{2}$ Gorsky State Agrarian University, Vladikavkaz, 362040, ${ }^{3}$ Kabardino-Balkarian State Agrarian University named after Kokov, Nalchik, 360030, ${ }^{4}$ Kabardino-Balkarian State University H.M. Berbekov, Nalchik, 360030, ${ }^{5}$ NorthOssetian State University named after K.L. Khetagurov, Vladikavkaz, 362025, Maykop State Technological University, Maykop 385000, Russian Federation
\end{abstract}

Journal of Livestock Science (ISSN online 2277-6214) 11: 14-19

Received on 1/11/2019; Accepted on 6/1/2020

doi. 10.33259/JLivestSci.2020.14-19

\begin{abstract}
Increasing the quality of food products through the prudent use of natural adsorbents is becoming a topical problem in agriculture in conditions of anthropogenic heavy metal contamination. The purpose of the study is to work out a method for detoxifying heavy metals by using natural adsorbents such as local zeolite and vitamin $\mathrm{C}$ as an example of the implementation of standards and requirements for environmental food safety in animal husbandry in the territories with high anthropogenic pollution. Using the analogue method three groups of cows were formed with account of origin, age, body weight and lactation performance. To determine the heavy metal concentration, the spectrophotometric method was applied. It was experimentally established that in order to enhance the quality of dairy products in the territory with the man-made contamination, it is advisable to supplement the diets of lactating cows with zeolite and vitamin C (the recommended doses are 3\% and $0.04 \%$ of the dry matter norm respectively). Due to the combined use of these natural adsorbents, zinc concentration in the cows' blood decreased 2.04 times, lead -2.53 times and cadmium - 3.65 times. The cow milk increased in mass fraction of fat by $0.22 \%$ and protein by $0.20 \%$; at the same time zinc concentration lowered 3.47 times, lead - 2.76 times and cadmium - 3.09 times. At that, the content of these toxicants in dairy products was lower than the maximum allowable concentration (MAC).
\end{abstract}

Keywords: animal husbandry; anthropogenic pollution; heavy metals; natural adsorbents; detoxification; physical-chemical properties of milk and meat. 


\section{Introduction}

Most large cities suffer from constant emissions of harmful substances into the atmosphere which exceed the maximum allowable concentration (MAC) in terms of many parameters. This factor causes the accumulation of heavy metals. In Russia, the Republic of North Ossetia - Alania (RNO - Alania) is one of such regions with high concentration of mining and processing enterprises. Large non-ferrous metal processing plants located in this territory are the main sources of anthropogenic environmental pollution with heavy metals. Over the last few years, the monitoring of heavy metals content in soil and fodder plants has indicated that lead content was 8-10 times higher than background levels (Kokaeva et al., 2015; Tsalieva et al., 2017).

Given the high level of contamination of soils and fodder plants with various types of toxicants, including heavy metals, a number of technological methods are employed to reduce the toxicity of dairy products obtained from cows grown in the territory with the anthropogenic pollution. Environmental safety of milk in many aspects depends on feeding conditions for lactating cows. One of the ways of rational environmental management in the territory with the man-made pollution is to block migration of toxicants along the trophic chain: soil-plant-feedanimal-food products (Temiraev et al., 2009; Baeva, Tedtova, 2009; Temiraev et al., 2017). The solution to this issue to a large extent determines food security in the region and commodity flows of food products (Kuzmin, 2015; Kuzmin, 2016).

Heavy metals are toxic due to the fact that they bind with proteins and form insoluble compounds altering properties and inactivating a number of vital enzymes. At the same time, these xenobiotics reduce the physicochemical and technological properties of dairy raw materials, making it difficult or impossible to prepare high-quality foodstuffs. All natural zeolite rocks crystallize from volcanic rocks capable of absorbing toxins, heavy metals, mold, chemicals and unpleasant odors (Temiraev et al., 2009).

Vitamin C (ascorbic acid) is an antioxidant that activates the protective function of the body. This reduces the number of free radicals that damage healthy cells. Vitamin $\mathrm{C}$ very effectively removes heavy metals from the body (Tsalieva et al., 2017).

Therefore, it seems urgent to raise the quality of dairy products and intensify metabolism in lactating cows through the rational use of natural adsorbents for the removal of heavy metals in industrialized territories in order to demonstrate the implementation of standards and requirements for environmental food safety in animal husbandry (Temiraev et al., 2017; Tedtova et al., 2017; Temiraev et al., 2011).

The present study aims to work out a method for detoxifying heavy metals by using natural adsorbents such as local zeolite and vitamin $\mathrm{C}$ as an example of the implementation of standards and requirements for environmental food safety in animal husbandry in the territories with high anthropogenic pollution.

\section{Material and methods}

The experimental part of the work with cows of black-motley breed was carried out under the conditions of the agricultural-production cooperative "Vesna" in Digorskiy district of RNO - Alania (Longitude: 44"40'04" East, Latitude: $43^{\circ} 02^{\prime} 12^{\prime \prime}$ North. Altitude $671 \mathrm{~m}$ ). In the experiment, 30 cows were selected and divided into three groups of 10 cows each using the analogue-pair method with account of origin, age, body weight, previous lactation performance and milkfat percentage. The scheme of the experiment is presented in Table 1.

Analysis of feed samples having selected in the territory of the collective farm "40 Let Oktyabrya" in Mozdoksky District of RNO-Alania showed that the zinc content exceeded the maximum permissible concentration (MPC) by a factor of 2.5-3.6, lead - 3.0-4.5 and cadmium - 1.9-2.5.

The cows in all three groups consumed diets balanced in accordance with the existing nutritional standards. However, the concentrations of zinc, lead and cadmium in these diets exceeded the maximum permissible level. The feeding regimen of the cows of the two experimental groups was supplemented with local zeolite (the Ursdon deposit, Digorskiy district of RNO - Alania) as a natural source of macro- and micronutrients and an adsorbent for the removal of heavy metal salts. Zeolite is also used as a medium for ion exchange in some biochemical transformations during the digestive process. Apart from zeolite, the diets of the 2-experimental group were supplemented with vitamin $\mathrm{C}$, a natural adsorbent and antioxidant, in the form of the drug Ascorbic Acid.

Vitamin C was purchased from a representative of Feed Resources LLC (Russia). Ascorbic acid (vitamin C) is a biologically active feed additive, which is represented by the ascorbin preparation, produced in our country in the form of a white powder, readily soluble in water, has a crystalline structure, odorless and with a specific acidic taste. He has a melting point $+190+193^{\circ} \mathrm{C}$. The preparation ascorbin vitamin $\mathrm{C}$ in the form of the active substance contains up to $99 \%$. The preparations zeolite and vitamin $\mathrm{C}$ were introduced into the standard compound feed composition with the help of a dispenser evenly.

Milk productivity of the cows used in the experiment was established by doing the control milking once a month. On the days of the control milking, the chemical composition of milk was determined according to conventional practices.

The content of heavy metals in the samples of feedstuffs, blood and milk was analysed using the atomic adsorption method with the help of the spectrophotometer AAZ-115-M1 in the laboratory of agroecology of the Gorsky State Agrarian University, Russian Federation). The study of the digestive metabolism was implemented using conventional practices and based on the results of rumen contents analysis (Kurilov, Krotkova, 1971) and 
morphological and biochemical blood parameters (Fyodorov, Kuzmin, 2013) in the cows used in the experiment. All the figures collected during the experiment were subjected to Student's t-test analysis using Microsoft Excel. The daily ration of experimental animals is presented in table 2.

Table 1. Scheme of the scientific and production experiment

\begin{tabular}{|l|c|c|c|c|}
\hline \multicolumn{1}{|c|}{ Group } & $\begin{array}{c}\text { The number of } \\
\text { animals in the } \\
\end{array}$ & \multirow{2}{*}{$\begin{array}{c}\text { Basis diet } \\
\text { group }\end{array}$} & & \multicolumn{2}{c|}{$\begin{array}{c}\text { The dose of feeding drugs, \% of the norm of dry } \\
\text { matter of the diet }\end{array}$} \\
\cline { 4 - 5 } & 10 & OP & Zeolite & Vitamin C \\
\hline 1-Control & 10 & OP & 3,0 & - \\
\hline 2-Experimental & 10 & OP & 3,0 & 0,04 \\
\hline 3-Experimental & & & - & - \\
\hline
\end{tabular}

Table 2 - The daily ration of feeding cows

\begin{tabular}{|l|l|l|}
\hline \multicolumn{1}{|c|}{ Indicators } & \multicolumn{1}{|c|}{$\begin{array}{c}\text { Normally } \\
\text { required }\end{array}$} & $\begin{array}{l}\text { Actual } \\
\text { Content }\end{array}$ \\
\hline Grass pasture, $\mathrm{kg}$ & - & 28 \\
\hline Green mass of alfalfa, $\mathrm{kg}$ & - & 11 \\
\hline Compound feed typical, kg & - & 3.4 \\
\hline Molasses feed kg & & 0.42 \\
\hline Table salt, g & - & 73 \\
\hline Copper sulfate, mg & - & 213 \\
\hline Cobalt chloride, g & - & 20.16 \\
\hline Manganese sulfate, g & - & 1200 \\
\hline Potassium iodide, mg & - & 10.30 \\
\hline The diet contains: & & \\
\hline exchange energy, MJ & 126 & 128.3 \\
\hline dry matter, kg & 14.1 & 14.8 \\
\hline crude protein, g & 1630 & 1592 \\
\hline digestible protein, g & 1060 & 1089 \\
\hline crude fiber, g & 3500 & 3545 \\
\hline starch, g & 1435 & 1487 \\
\hline sugar, g & 955 & 958 \\
\hline crude fat, g & 340 & 394 \\
\hline calcium g & 73 & 88.75 \\
\hline phosphorus, g & 51 & 48.9 \\
\hline magnesium g & 22 & 26.24 \\
\hline potassium g & 82 & 194 \\
\hline sulfur, g & 27 & 31.9 \\
\hline iron mg & 850 & 2529 \\
\hline copper mg & 95 & 95 \\
\hline zinc mg & 635 & 915 \\
\hline lead mg & - & 337.3 \\
\hline cadmium mg & - & 25.2 \\
\hline & & \\
\hline & & \\
\hline
\end{tabular}

\section{Results and Discussion}

Special attention was paid to the content of heavy metals in animal feeds. At that, the concentration of toxicants in $1 \mathrm{~kg}$ of diet dry matter was an important indicator when analysing the cows' feeding regimens (Table 3 ).

It was found that the total daily concentration of heavy metals in the dry matter of the winter diet was higher than that of the summer diet: zinc - by $8.07 \%$, lead - by $12.11 \%$ and cadmium - by $8.18 \%$. This is due to the locally produced coarse forage contained in the winter diet. At the same time, the concentration levels of these elements were elevated in both summer and winter diets of the experiment cows. It is known that heavy metals can suppress the intensity of rumen metabolism, which is confirmed by the data of Table 4.

Due to the high concentration of macro- and microelements, zeolite when used in combination with vitamin $\mathrm{C}$ caused a shift in the $\mathrm{pH}$ of rumen contents towards neutral. At the same time, there was a significant $(\mathrm{P}>0.95)$ increase in the $\mathrm{pH}$ of rumen fluid by $8.24 \%$ in the 2-experimental group of cows if compared with the control analogues.

The combined use of zeolite and vitamin $\mathrm{C}$ led to a significant $(\mathrm{P}>0.95)$ increase in the number of ciliates of rumen contents by 84 thousand/ml in the 2 -experimental group as compared to the control cows. Ciliates produce a 
large portion of cellulase, therefore, cellulase activity in rumen fluid of the cows of the 2-experimental group was significantly $(\mathrm{P}>0.95)$ higher by $3.38 \%$ than in the control animals.

The adsorption of heavy metals in the gastrointestinal tract intensified the synthesis of proteinases by forestomach microflora, so their activity in rumen fluid of the 2-experimental cows was significantly $(\mathrm{P}>0.95)$ higher by $4.32 \%$ than in the control group. Moreover, ammonia concentration in rumen fluid of the 2-experimental group was significantly $(\mathrm{P}>0.95)$ lower by $8.6 \%$ as compared to the control animals. This indicates that rumen microflora of the 2-experimental cows markedly better utilized ammonia for protein synthesis.

In contrast to the control analogues, the combined supplementation of zeolite and vitamin $\mathrm{C}$ to the diets of the 2-experimental cows resulted in significant $(\mathrm{P}>0.95)$ intensification of synthesis of volatile fatty acids (primarily acetic acid - by $2.06 \%)$ in rumen fluid and a simultaneous decrease in the level of butyric acid by $2.23 \%(\mathrm{P}>0.95)$. In other words, this led to intensification of hydrolysis of animal feeds' cellulose and correction of metabolites' fermentation according to the desired direction, and this stimulated an increase in mass fraction of milk fat.

Detoxification of heavy metals through the prudent use of natural adsorbents in diets of lactating cows positively influenced their milk productivity (Table 5).

In terms of average daily yield of milk with natural fat content, the cows of the control group $(22.09 \pm 0.54 \mathrm{~kg})$ and the animals of the 1-experimental $(22.53 \pm 0.40 \mathrm{~kg})$ and the 2 -experimental $(22.58 \pm 0.50 \mathrm{~kg})$ groups did not reveal any significant $(\mathrm{P}<0.95)$ differences.

Table 3 - Concentration of toxicants in $1 \mathrm{~kg}$ of diet dry matter

\begin{tabular}{|l|l|l|l|}
\hline Indicator & \multirow{2}{*}{$\begin{array}{l}\text { Unit } \\
\text { measuring }\end{array}$} & Diet & \\
\cline { 3 - 4 } & $\mathrm{mg}$ & Summer & Winter \\
\hline Zinc & $\mathrm{mg}$ & 102.07 & 110.31 \\
\hline Lead & $\mathrm{mg}$ & 28.99 & 32.50 \\
\hline Cadmium & 2.20 & 2.38 \\
\hline
\end{tabular}

Table 4 - Characteristics of rumen contents of the experiment cows

\begin{tabular}{|l|l|l|l|}
\multicolumn{2}{c}{ Indicator } & \multicolumn{3}{c|}{ Group } \\
\cline { 2 - 4 } & \multicolumn{1}{|c|}{1 -Control } & \multicolumn{1}{c|}{ 2-Experimental } & $\begin{array}{c}3- \\
\text { Experimental }\end{array}$ \\
\hline $\mathrm{pH}$ & $6.46 \pm 0.17$ & $6.86 \pm 0.10$ & $7.04 \pm 0.11$ \\
\hline Ammonia, mmol/L & $15.64 \pm 0.19$ & $14.69 \pm 0.24$ & $14.40 \pm 0.22$ \\
\hline Ciliates, thousand/ml & $358 \pm 5.3$ & $428 \pm 4.5$ & $442 \pm 4.8$ \\
\hline Cellulolytic activity, \% & $15.18 \pm 0.44$ & $18.48 \pm 0.41$ & $18.56 \pm 0.37$ \\
\hline Proteolytic activity, \% & $43.08 \pm 0.69$ & $46.97 \pm 0.80$ & $47.40 \pm 0.78$ \\
\hline VFA, mmol/100 ml & $11.11 \pm 0.15$ & $12.47 \pm 0.11$ & $12.65 \pm 0.12$ \\
\hline $\begin{array}{l}\text { of which, \%: } \\
\text { acetic acid }\end{array}$ & $63.00 \pm 0.71$ & $64.98 \pm 0.67$ & $65.06 \pm 0.61$ \\
\hline propionic acid & $19.46 \pm 0.32$ & $19.58 \pm 0.34$ & $19.54 \pm 0.31$ \\
\hline butyric acid & $12.43 \pm 0.21$ & $10.31 \pm 0.23$ & $10.20 \pm 0.21$ \\
\hline valeric acid & $3.37 \pm 0.19$ & $3.25 \pm 0.14$ & $3.30 \pm 0.20$ \\
\hline hexanoic acid & $1.74 \pm 0.07$ & $1.88 \pm 0.06$ & $1.90 \pm 0.04$ \\
\hline
\end{tabular}

Table 5 - Milk productivity of the experiment cows

$\mathrm{n}=10$

\begin{tabular}{|l|l|l|l|}
\hline \multirow{2}{*}{ Indicator } & \multicolumn{3}{c|}{ Group } \\
\cline { 2 - 4 } & \multicolumn{1}{|c|}{ 1-Control } & \multicolumn{1}{c|}{ 2-Experimental } & \multicolumn{1}{c|}{ 3-Experimental } \\
\hline Average daily milk yield, kg & $22.09 \pm 0.54$ & $22.53 \pm 0.40$ & $22.58 \pm 0.50$ \\
\hline $\begin{array}{l}\text { Milk containing, \%: } \\
\text { fat }\end{array}$ & $3.45 \pm 0.05$ & $3.65 \pm 0.04$ & $3.67 \pm 0.07$ \\
\hline protein & $3.23 \pm 0.03$ & $3.40 \pm 0.03$ & $3.43 \pm 0.04$ \\
\hline Yield of milk with 3.4\%-standard fat content & $22.41 \pm 0.30$ & $24.18 \pm 0.21$ & $24.37 \pm 0.26$ \\
\hline Ratio to the control analogues, \% & 100.0 & 107.9 & 108.7 \\
\hline
\end{tabular}

The combined intake of the natural adsorbents (zeolite and vitamin C) intensified cellulase production by rumen microflora, and this, in turn, accelerated cellulose hydrolysis by activating the fermentation of its metabolites with production of large amounts of acetic acid. This resulted in a significant $(\mathrm{P}>0.95)$ increase in milkfat by $0.22 \%$ in the cows from the 2-experimental group when compared to the control analogues.

Along with this, milk processing enterprises make purchases according to the yield of milk with standard fat content, which, in RNO - Alania, is equal to 3.4\%. It was established that due to the combined use of the natural adsorbents (zeolite and vitamin $\mathrm{C}$ ), the cows of the 2-experimental group showed a significant $(\mathrm{P}>0.95)$ increase in the yield of milk with standard fat content by $8.7 \%$ when compared to the animals of the control group. 
Disturbing the ecology of feeding brings about a marked negative effect on physical and chemical properties of lactating cows' milk (Table 6).

There were no significant $(\mathrm{P}<0.95)$ differences between the compared groups of cows with respect to milk acidity. At that, in terms of acidity, the samples of the experiment cows' milk were classed as 1st grade milk.

Due to the combined supplementation of zeolite and vitamin $\mathrm{C}$ to diets with a high content of heavy metals, the cows of the 2-experimental group demonstrated an improvement in a number of other physical and chemical parameters of milk. For example, in contrast to the control analogues, milk density of the 2-experimental animals increased significantly $(\mathrm{P}>0.95)$ by $0.67^{\circ} \mathrm{A}$, dry matter content - by $0.54 \%$, vitamin $\mathrm{C}-$ by $21.01 \%$ and vitamin $\mathrm{A}-$ by $36.84 \%$.

Table 6 - Physical and chemical properties of milk

\begin{tabular}{|l|l|l|l|}
\hline \multicolumn{1}{|c|}{ Indicator } & \multicolumn{3}{c|}{$\mathrm{n}=10$} \\
\cline { 2 - 4 } & \multicolumn{1}{c|}{ 1-Control } & \multicolumn{1}{c|}{ 2-Experimental } & 3-Experimental \\
\hline Density, ${ }^{\circ} \mathrm{A}$ & $28.17 \pm 0.11$ & $28.77 \pm 0.13$ & $28.84 \pm 0.14$ \\
\hline Acidity, ${ }^{\circ} \mathrm{T}$ & $17.84 \pm 0.22$ & $17.77 \pm 0.22$ & $17.89 \pm 0.19$ \\
\hline Dry matter, \% & $12.28 \pm 0.08$ & $12.78 \pm 0.05$ & $12.82 \pm 0.10$ \\
\hline Fat content, \% & $3.45 \pm 0.05$ & $3.65 \pm 0.04$ & $3.67 \pm 0.07$ \\
\hline Protein content, \% & $3.23 \pm 0.03$ & $3.40 \pm 0.03$ & $3.43 \pm 0.04$ \\
\hline Lactose, \% & $4.55 \pm 0.04$ & $4.59 \pm 0.06$ & $4.55 \pm 0.05$ \\
\hline Ash, \% & $1.05 \pm 0.04$ & $1.14 \pm 0.04$ & $1.17 \pm 0.03$ \\
\hline Vitamin C, mg/L & $15.75 \pm 0.32$ & $19.55 \pm 0.42$ & $19.94 \pm 0.34$ \\
\hline Vitamin A, $\mathrm{mg} / \mathrm{L}$ & $0.24 \pm 0.03$ & $0.34 \pm 0.03$ & $0.38 \pm 0.03$ \\
\hline
\end{tabular}

Table 7 - Diameter and number of fat globules, composition and properties of milk protein

\begin{tabular}{|c|c|c|c|}
\hline \multirow{2}{*}{ Indicator } & \multicolumn{3}{|c|}{ Group } \\
\hline & 1-Control & 2-Experimental & 3-Experimental \\
\hline \multicolumn{4}{|c|}{ Diameter and number of fat globules } \\
\hline Total fat, \% & $3.45 \pm 0.05$ & $3.65 \pm 0.04$ & $3.67 \pm 0.07$ \\
\hline Diameter of fat globules, $\mu \mathrm{m}$ & $3.63 \pm 0.03$ & $3.58 \pm 0.02$ & $2.83 \pm 0.02$ \\
\hline Number of fat globules, billion $/ \mathrm{cm}^{3}$ & $3.79 \pm 0.09$ & $3.86 \pm 0.10$ & $5.80 \pm 0.09$ \\
\hline \multicolumn{4}{|c|}{ Composition and properties of milk protein } \\
\hline Total protein, $\%$ & $3.23 \pm 0.03$ & $3.40 \pm 0.03$ & $3.43 \pm 0.04$ \\
\hline Casein, \% & $2.30 \pm 0.02$ & $2.49 \pm 0.03$ & $2.51 \pm 0.02$ \\
\hline Serum protein, $\%$ & $0.93 \pm 0.003$ & $0.91 \pm 0.004$ & $0.92 \pm 0.006$ \\
\hline $\begin{array}{l}\text { Casein composition, } \% \text { : } \\
\alpha \text {-casein }\end{array}$ & $32.51 \pm 0.24$ & $34.46 \pm 0.20$ & $34.63 \pm 0.22$ \\
\hline$\beta$-casein & $52.15 \pm 0.34$ & $54.29 \pm 0.41$ & $54.51 \pm 0.32$ \\
\hline$\gamma$-casein & $15.34 \pm 0.14$ & $11.25 \pm 0.13$ & $10.86 \pm 0.17$ \\
\hline
\end{tabular}

Table 8 - Heavy metals content in milk of the experiment cows

\begin{tabular}{|l|r|r|r|}
\hline \multirow{2}{*}{ Indicator } & \multicolumn{3}{c|}{$\mathrm{n}=10$} \\
\cline { 2 - 4 } & \multicolumn{1}{|c|}{ 1-Control } & 2-Experimental & 3-Experimental \\
\hline Zinc, $\mathrm{mg} / \mathrm{L}(\mathrm{MAC}=5.0 \mathrm{mg} / \mathrm{L})$ & $6.80 \pm 0.14$ & $2.61 \pm 0.17$ & $1.96 \pm 0.12$ \\
\hline Lead, $\mathrm{mg} / \mathrm{L}(\mathrm{MAC}=0.05 \mathrm{mg} / \mathrm{L})$ & $0.080 \pm 0.003$ & $0.045 \pm 0.002$ & $0.029 \pm 0.004$ \\
\hline Cadmium, $\mathrm{mg} / \mathrm{L}(\mathrm{MAC}=0.02 \mathrm{mg} / \mathrm{L})$ & $0.034 \pm 0.001$ & $0.019 \pm 0.002$ & $0.011 \pm 0.002$ \\
\hline
\end{tabular}

Along with an increase in the percentage of milkfat, the joint use of the tested adsorbent drugs optimized proteinase secretion by rumen microflora. This contributed to a significant $(\mathrm{P}>0.95)$ improvement in milk protein content by $0.20 \%$ in the cows of the 2-experimental group in comparison with the control analogues.

The percentages of fat and protein in milk are of high importance when determining the purposes of milk production. Considering a significant $(\mathrm{P}>0.95)$ increase in mass fraction of fat by $0.22 \%$ and protein - by $0.20 \%$ in milk of the 2-experimental group against the control analogues, we carried out a comparative analysis of the diameter and number of fat globules, as well as composition and properties of milk protein in the cows selected for the experiment (Table 7).

It was established that the combined supplementation of zeolite and vitamin $\mathrm{C}$ to diets high in heavy metals exerted a negative impact on the diameter and number of fat globules. Milk of the 2-experimental group of cows, compared with the control animals, contained significantly $(\mathrm{P}>0.95)$ more fat globules by $53.0 \%$, but their diameter 
reduced by $22.0 \%(\mathrm{P}>0.95)$. It means that qualitative characteristics of milk fat of the 2-experimental cows indicate a deterioration in the properties of dairy raw materials for butter-making.

The adequacy of milk for cheese-making depends on composition and properties of its proteins. Milk of the 2 -experimental group of cows was found to contain significantly $(\mathrm{P}>0.95)$ more casein by $0.21 \%$. Only $\alpha$ - и $\beta$ casein coagulate under the influence of rennet enzyme, but $\gamma$-casein does not form part of casein micelles. Due to the combined use of the natural adsorbents (zeolite and vitamin $\mathrm{C}$ ), casein in milk of the 2-experimental group of cows was significantly $(\mathrm{P}>0.95)$ richer in $\alpha-$ и $\beta$-fractions by $2.12 \%$ and $2.36 \%$ respectively compared with the control analogues, but at the same time it was lower in $\gamma$-casein - by $4.48 \%(\mathrm{P}>0.95)$.

However, when studying consumer properties of dairy products, environmental safety of such products is as important as their traditional physical and chemical parameters. Environmental safety is based on the evaluation of the content of various toxicants in milk, including heavy metals (Table 8).

The research results demonstrated that the natural adsorbents (zeolite and vitamin $\mathrm{C}$ ), taken in combination, produced the most powerful detox effect in the body of the cows. The concentration of zinc in milk of the 2experimental group significantly $(\mathrm{P}<0.05)$ lowered 3.47 times, lead -2.76 times and cadmium -3.09 times when compared to the control animals. At that, the content of these heavy metals in dairy products of the 2-experimental group was also lower than the maximum allowable concentration.

Conclusion. 1). In the territories with high levels of anthropogenic contamination such as RNO - Alania, in order to enhance the quality of dairy products, improve sanitary-hygienic qualities of milk and intensify metabolism of lactating cows, it is advisable, during heavy metal detox, to supplement the diets with zeolite and vitamin $\mathrm{C}$ (the recommended doses are $3 \%$ and $0.04 \%$ of the dry matter norm respectively).

2). Zeolite and vitamin $\mathrm{C}$, taken together, exerted the most pronounced detox effect in the body of the cows. The concentration of zinc in milk of the 2-experimental cows significantly $(\mathrm{P}<0.05)$ lowered 3.47 times, lead -2.76 times and cadmium - 3.09 times when compared to the control animals. At that, the content of these heavy metals in dairy products of the 2-experimental group of cows was also below the maximum permissible levels.

The research results demonstrated that the natural adsorbents (zeolite and vitamin $\mathrm{C}$ ), taken in combination, produced the most powerful detox effect in the body of the cows. The concentration of zinc in milk of the 2experimental group significantly $(\mathrm{P}<0.05)$ lowered 3.47 times, lead -2.76 times and cadmium -3.09 times when compared to the control animals. At that, the content of these heavy metals in dairy products of the 2-experimental group was also lower than the maximum allowable concentration.

\section{References}

1). Baeva Z.T., Tedtova V.V. 2009. Improving Technological Properties of Cow's Milk. Veterinary Physician, 5: 48-52.

2). Fyodorov M.V., Kuzmin E.A. 2013. Agriculture and Economic Security of Russia: Retrospective Research. Journal of International Scientific Researches 5: 42-45.

3). Kokaeva M.G., Plieva Z.K., Temiraev R.B., Gurtsieva D.O. 2015. Biological and Productive Resources of Lactating Cows at Denitrification. Scientific Journal of KubSAU (Polythematic online scientific journal of Kuban State Agrarian University) 111, no. 07. Available at: http://ej.kubagro.ru/2015/07/pdf/104.pdf.

4). Kurilov N.V., Krotkova A.P. 1971. Physiology and Biochemistry of Digestion in Ruminants. Kolos Publ.

5). Kuzmin E.A. 2015. Food Security Modelling. Biosciences Biotechnology Research Asia, 12 (Spl. Edn. 2): 77381.

6). Kuzmin E.A. 2016. Sustainable Food Security: Floating Balance of Markets. International Journal of Economics and Financial Issues 6: 37-44.

7). Tedtova V.V., Kozhokov M.K., Shugusheva L.H., Kanukova V.N., Baeva A.A., Vityuk L.A. 2017. Preventive and detoxicative action of probiotics on metabolism and consumer quality of broilers meat. Journal of Pharmaceutical Sciences and Research. 9: 997-1001.

8). Temiraev R.B., Baeva Z.T., Teziev U.I., Gazdarov A.A. 2009. How to Prevent Milk Products from Heavy Metals Contamination. Dairy Industry, 5: 73-74.

9). Temiraev R.B., Kozyrev S.G., Kononenko S.I., Baeva A.A., Bobyleva L.A., Kalabekov A.L. 2017. Impact of the breed-specific characteristics on the metabolism and heavy metal accumulation in the organs and tissues of calves. Journal of Pharmaceutical Sciences and Research. 9. 6: 780-784.

10). Temiraev R.B., Tedtova V.V., Baeva Z.T., Mosesyan L.R. 2011. Method to Improve Ecological and Nutritional Properties of Milk and Dairy Products in the Conditions of the Foothill Zone of the North Caucasus. Sustainable Development of Mountain Territories 7, no. 1: 97-104.

11). Temiraev V.K., Kairov V.R., Temiraev R.B., Kubatieva Z.A., Gukezhev V.M. 2017. Method to improve productive performance and digestion exchange of broiler chickens with reduced risk of aflatoxicosis. Ecology, Environment and Conservation. 23: 554-561

12). Tsalieva L.V., Temiraev R.B., Kononenko S.I., Dzagurov B.A., Gazzaeva M.S., Grevtsova S.A. 2017. Ecological and consumer properties of pig meat from different breeds produced in technogenic zone. Journal of Pharmaceutical Sciences and Research. 9: 2397-2400. 